\title{
Legal and Policy Implications on the Post-Kyoto Protocol System: A Korean Lawyer's Viewpoint
}

\author{
Sung Ja Cho*
}

In 1997, the Kyoto Protocol was established as the first global treaty imposing legallybinding targets on the developed countries, imploring countries to curb greenhouse gases emissions from 2008 to 2012. In 2012, the Doha Amendment was agreed upon to extend KP for seven more years, from 2013 to 2020. However, it is not yet in force due to lack of ratification. The UN is trying to build a new international climate change system to succeed $K P$, which will encompass both the developing countries and the developed countries after 2020. The US, China, the EU and Japan are the four largest GHG emitters. Through the first period of KP, the international climate change system became an international political and economic network, creating new paradigms for energy resources, ways of life, carbon market, and economic development, et cetera. This article will show some of the underlying political and economic dynamics and responses of those four countries and Korea around the PostKP negotiations.

\section{Keywords}

Kyoto Protocol, Post-Kyoto Protocol, Greenhouse Gas Emission, Carbon Trading Market, Global Warming, Korean Strategies

* Associate Professor of Law at Kangwon National University, Korea. B.A.(SNU), M.A.(Soongsil Univ.), J.D. (Temple); Attorney-at-Law (NY \& NJ Bar). ORCID: http://orcid.org/0000-0001-8443-2326 This article was supported by 2012 Research Grant from Kangwon National University. The author may be contacted at: sungjac@ kangwon.ac.kr / Address: 306, School of Law, Kangwon National University, Chuncheon-city, Kangwon Province 200-701 Korea.

DOI: http://dx.doi.org/10.14330/jeail.2014.7.2.09 


\section{Introduction}

In 1968, ecologist Garrett Hardin showed how the commons cannot survive, ${ }^{1}$ analyzing the global population problem as a dilemma with "no technical solution." Hardin said: "we are locked into a system of 'fouling our own nest,' so long as we behave only as independent, rational, free-enterprisers" because "the rational individual finds that his share of the cost of the wastes he discharges into the commons is less than the cost of purifying or of not releasing his wastes into the commons."

Within half a century, Hardin's logic can be precisely applied to one of the transnational common good, ${ }^{3}$ i.e., the air. The World Bank's report, "Turn Down the Heat: Why a $4^{\circ} \mathrm{C}$ Warmer World Must be Avoided" maintains that if the world fails to keep its earlier promise to reduce greenhouse gas ("GHG") emissions by 2012, global temperature would rise more than $4^{\circ} \mathrm{C}$ by 2060 compared to pre-industrial times. ${ }^{4}$ When the global temperature increases by $4^{\circ} \mathrm{C}$, the world would be marked by extreme heat-waves, a lack of global food stocks, loss of ecosystems and biodiversity, ocean acidification, and life-threatening sea level rise, etc. ${ }^{5}$ Although nations have agreed on the need to stop the climate change impacts, they still want to maintain its GHG emissions at the same time. The countries finally signed at the Kyoto Protocol ("KP") in 1997 as the first global agreement imploring GHG emissions control; KP started with legally-binding targets to curb GHG emissions of 38 developed countries classified as Annex I nations from 2008 to $2012{ }^{6}$ Up until 2008, more than 190 nations had agreed to extend KP, requiring developed countries to reduce GHG emissions by at least 5percent below 1990 levels in the commitment

1 G. Hardin, The Tragedy of the Commons, 162 SCIENCE 1243-1248 (1968), available at http://www.sciencemag.org/ content/162/3859/1243.full (last visited on Oct. 7, 2014).

2 Id. at 1245.

3 S. Ansari et al., Constructing a Climate Change Logic: An Institutional Perspective on the "Tragedy of the Commons," 24 OrG. ScI., 1014-1040 (2013). [Emphasis added]

4 World Bank, Climate Change Report Warns of Dramatically Warmer World This Century, Nov. 18, 2012, available at http://www.worldbank.org/en/news/feature/2012/11/18/Climate-change-report-warns-dramatically-warmer-worldthis-century (last visited on Sept. 26, 2014). According to the report, maintaining the current level of greenhouse gas emissions would result in extreme heat-waves and a life-threatening sea level rise; adverse effects of global warming that were "tilted against many of the world's poorest regions"; and undermining development efforts and goals. As such, the World Bank asks for increased support for adaptation, mitigation, inclusive green growth and climate-smart development.

5 Id.

6 UnfCCC, Uniting on Climate: A Guide to a Climate Change and the Kyoto Protocol 28 (2007), available at http:// unfccc.int/resource/docs/publications/unitingonclimate_eng.pdf (last visited on Oct. 23, 2014). 